\title{
EFEKTIVITAS PELATIHAN PEMAKNAAN SURAT AL-INSYIRAH UNTUK MENGURANGI STRES MAHASISWA YANG SEDANG MENGERJAKAN SKRIPSI
}

\section{THE EFFECTIVENESS OF TRAINING SURAT AL-INSYIRAH MEANING IN REDUCING STUDENTS' STRESS WHO ARE DOING THESIS}

\author{
Aning Az Zahra \\ Satih Saidiyah \\ Fakultas IImu Sosial dan Humaniora Universitas Islam Negeri Sunan Kalijaga Yogyakarta \\ E-mail: aningazzahra@rocketmail.com / satihsaidiyah@yahoo.co.id
}

\begin{abstract}
This study aims to determine the effectiveness of training meaning Surat Al-Insyirah in reducing students' stress that are doing thesis. Subjects in this study consisted of 15 subjects which 8 subjects into the experimental group and 7 subjects into the control group. Characteristic's subjects are: 1) Student in UIN Sunan Kalijaga especially majoring of scientis and technology, 2) Engaged in a thesis, 3) Willing to be a subject of study. This study considered true experimental research. The test results using statistical analysis techniques Mann Whitney Test showed that the Mann Whitney $U$ as post-test at $p=0.049(p<0.05$, significant), so that suggests there were differences in post-test scores between the experimental group and the control group. The results of statistical tests wicoxon signed Ranks to compare the post-test and pre-test between the experimental and control groups revealed the value $p=0.025(p<0.05$, significant), so that it could be argued that there was a difference in scores of pre-test and post-test in the experimental group. While the results of the test statistic with Wilcoxon Signed Ranks to compare the post-test and pre-test in the control group revealed the value of $p=0.611$ ( $p>0.05$, not significant), so that it could be argued that there was no difference between the pre-test and post-test in the control group.
\end{abstract}

Keywords: Training Meaning Surat Al-Insyirah, Stress, Students Who Are Doing Thesis.

\begin{abstract}
ABSTRAK
Penelitian ini bertujuan untuk menguji efektivitas pelatihan pemaknaan Surat Al-Insyirah dalam mengurangi stres mahasiswa yang sedang mengerjakan skripsi. Subjek dalam penelitian ini terdiri atas 15 subjek di mana 8 subjek menjadi kelompok eksperimen dan 7 subjek menjadi kelompok kontrol. Karakteristrik subjek di antarannya: 1) Mahasiswa UIN Sunan Kalijaga khususnya mahasiswa Fakultas Sains dan Teknologi, 2) Sedang mengerjakan skripsi, 3) Bersedia menjadi subjek penelitian. Penelitian ini dikategorikan penelitian true eksperimen. Hasil uji statistika dengan menggunakan teknik analisis Mann Whitney Test menggungkap bahwa nilai Mann Whitney $U$ saat pascates sebesar $p=0,49(p<0,05$, signifikan) sehingga dapat disimpulkan ada perbedaan skor pascates antara kelompok eksperimen dan kelompok kontrol. Hasil uji statistik dengan Wicoxon Signed Ranks untuk membandingkan pascates dan prates antara kelompok eksperimen dan kelompok kontrol menunjukkan nilai $p=0,025(p<0,05$, signifikan) sehingga dapat dikemukakan bahwa ada perbedaan skor prates dan pascates pada kelompok eksperimen. Sedangkan hasil uji statistik dengan Wilcoxon Signed Ranks untuk membandingkan pascates dan prates pada kelompok kontrol mengungkap nilai $p=0,611$ ( $p>0,05$, tidak signifikan) sehingga dapat dikemukakan bahwa tidak ada perbedaan hasil prates dan pascates pada kelompok kontrol.
\end{abstract}

Kata Kunci: Pelatihan Pemaknaan Al-Insyirah, Stres, dan Mahasiswa Yang Sedang Skripsi 
Masa dewasa awal merupakan masa seorang individu mengalami Ionjakan-Ionjakan persoalan hidup dibandingkan dengan masa remaja (Mappiare, 1983). Masa ini berkisar antara umur 20 tahun hingga 30 tahun (Santrock, 2007). Dewasa awal merupakan kelanjutan masa remaja yang memiliki ciri-ciri seperti usia produktif, usia memantapkan kedudukan, usia banyak problem, dan usia tegang dalam hal emosi (Mappiare, 1983). Mahasiswa termasuk dalam ranah dewasa awal.

Mahasiswa sebagai individu yang menempuh pendidikan perkuliahan atau pendidikan tinggi tidak luput dari stres. Menurut Heerdjan (1987), stres adalah suatu kekuatan yang mendesak atau mencekam yang menimbulkan suatu ketegangan dalam diri seseorang. Hal ini disebabkan oleh banyaknya tuntutantuntutan yang harus diemban oleh mahasiswa. Penelitian Shenoy (2000) menunjukkan bahwa tuntutan terhadap mahasiswa bisa merupakan sumber stres yang potensial. Hal tersebut disebabkan tanggung jawab baru yang harus dihadapi mahasiswa, misalnya meningkatkan prestasi akademik, kemandirian, dan tugas-tugas yang dinilai semakin berat termasuk skripsi.

Skripsi merupakan salah satu tugas yang wajib diselesaikan bagi mahasiswa yang ingin mandapatkan gelar sarjana (S1). Berdasarkan dari studi yang dilakukan terhadap mahasiswa yang sedang mengerjakan skripsi diketahui bahwa ketika mengerjakan skripsi mereka sering merasa bingung sendiri, jantung berdebar-debar, dan kurang bisa mengontrol emosi. Hasil penelitian yang dilakukan Lazarus dan Folkman (Yulianti, 2010) menunjukkan bahwa sumber stres mahasiswa yang sedang mengerjakan skripsi lebih banyak bersumber dari faktor eksternal, yaitu faktor dosen pembimbing $(16,88 \%)$ dan faktor kesulitan mendapatkan sumber pustaka $(16,88 \%)$. Pada umumnya tidak ada gejala stres yang sangat menonjol. Namun, ada beberapa gejala stres yang signifikan seperti gejala kognitif (29\%) berupa kesulitan berkonsentrasi dan mudah lupa, gejala behavioral (16\%) seperti membentak orang lain, gejala mental (18\%) seperti menyalahkan diri, cepat marah, tidak tenang, mimpi buruk, dan lain-lain; gejala fisik (19\%) seperti sakit kepala, sakit punggung, sesak nafas, diare, gatal-gatal, dan lain-lain.

Berkenaan dengan tingginya tingkat stres yang dialami mahasiswa yang sedang mengerjakan skripsi, dapatkah religiositas berperan dalam mengurangi stress? Hasil riset George dkk (Compton, 2005) menunjukkan bahwa keyakinan dan kegiatan keagamaan dapat berperan sebagai pencegah dan penyembuh terhadap stres. Hal senada diungkapkan oleh Koenig dkk (Ano \& Vasconcelles, 2005) bahwa koping religius berperan dalam membebaskan individu dari stress. Koping religius sendiri didefinisikan sebagai penggunaan 
keyakinan keagamaan atau perilaku keagamaan untuk memfasilitasi pemecahan masalah dan mencegah atau mengurangi konsekuensi negatif dari keadaan emosional kehidupan yang penuh stres. Dalam penelitian ini, keyakinan dan perilaku keagamaan yang hendak diketahui pengaruhnya adalah pemaknaan al-Qur'an surat al-Insyirah.

Al-Qur'an sebagai as-syifa mempunyai kekuatan untuk menangani dan menyembuhkan tekanan jiwa (Kuhsari, 2012). Rakhmat (2004) berpendapat bahwa ayat-ayat Al-Qur'an dapat menjadi suatu media terapi bagi seseorang. Hal ini sebagaimana difirmankan Allah 'azza wa jalla dalam Al-Qur'an Surat Yunus ayat 57: "Wahai manusia, sesungguhnya sudah datang dari Tuhanmu al-Qur'an yang mengandung pengajaran, penawar bagi penyakit batin (jiwa), tuntunan serta rahmat bagi orang-orang yang beriman."

Al-Insyirah adalah surat yang diturunkan Allah kepada Nabi Muhammad SAW ketika beliau mendapatkan amanah yang sangat berat dari Allah SWT. Surat tersebut diturunkan sebagai pelapang, sehingga Nabi Muhammad SAW semakin kuat untuk menjalani amanah dari Allah SWT tersebut. Surat tersebut diturunkan agar Rasulullah tabah dalam menjalankan risalah dan yakin bahwa di balik kesulitan pasti ada kemudahan (Al-Qur'an Terjemah,1999).

Di dalam surat tersebut terdapat beberapa aspek yang dapat diambil, yaitu aspek kelapangdadaan, aspek kepercayaan bahwa di setiap kesulitan pasti ada kemudahan serta etos kerja (Farida, 2011). Menurut Nashori (2008), kelapangdadaan adalah suatu kondisi psiko-spiritual yang ditandai oleh kemampuan menerima berbagai kenyataan yang tidak menyenangkan dengan tenang dan terkendali. Orang yang lapang dada memiliki kekuatan dalam jiwanya untuk bertahan dan tidak berputus asa manakala menghadapi berbagai situasi yang secara objektif tidak menyenangkan secara psikis dan menyakitkan secara fisik. Semakin tinggi kelapangdadan seseorang semakin mampu ia menghadapi realitas yang beragam, termasuk tidak menyenangkan (Nashori, 2008).

Salah satu ciri atau tipe orang yang sehat jiwa menurut Starbuck (Rakhmat, 2008) adalah optimis dan gembira. Orang yang sehat mengungkap bahwa pahala sebagai hasil jerih payah yang diberikan Tuhan (Rakhmat, 2008). Orang yang sehat dalam beragama adalah orang yang selalu berfikir positif. Surat alInsyirah juga berisi etos kerja yang mengandung unsur larangan untuk menyia-nyiakan waktu dan tiada hari tanpa perbaikan.

Berdasarkan latar belakang di atas maka peneliti ingin mengetahui "Efektivitas Pelatihan Pemaknaan Surat Al-Insyirah dalam Mengurangi Stres Mahasiswa yang Sedang Mengerjakan 
Skripsi". Hipotesis dari penelitian ini adalah (1) ada perbedaan tingkat stres mengerjakan skripsi pada mahasiswa Fakultas Sains dan Teknologi sebelum dan sesudah diberikan Pelatihan Pemaknaan Surat Al-Insyirah, tingkat stres berkurang setelah mendapatkan pelatihan dan (2) ada perbedaan tingkat stres mengerjakan skripsi mahasiswa Fakultas Sains dan Teknologi pada mahasiswa yang diberikan perlakuan dan tidak diberikan perlakuan. Mahasiswa yang diberikan perlakuan mempunyai tingkat stres lebih rendah daripada mahasiswa yang tidak diberikan perlakuan.

\section{METODE PENELITIAN}

\section{Subjek Peneltian}

Subjek dalam penelitian ini adalah mahasiswa Fakultas Sains dan Teknologi non-kependidikan (ilmu murni) UIN Sunan Kalijaga Yogyakarta yang sedang mengerjakan skripsi. Sebanyak 8 orang bertindak sebagai subjek eksperimen dan 7 orang sebagai kelompok kontrol.

Perlu disampaikan bahwa awalnya peneliti memperoleh sampel sebanyak 61 subjek, kemudian dikategorikan menjadi tiga tingkat yaitu rendah, sedang, dan tinggi.

Tabel 1. Kategorisasi Tingkat Stres Mahasiswa Fakultas Sains dan Teknologi non-kependidikan.

\begin{tabular}{lrrrl}
\hline \multirow{2}{*}{ No } & \multirow{2}{*}{ Skor } & \multicolumn{2}{c}{ Frekuensi } & \multirow{2}{*}{ Kategorisasi } \\
\cline { 3 - 4 } & & $\mathbf{F}$ & \multicolumn{1}{c}{$\mathbf{F \%}$} & \\
\hline 1. & $54-66$ & 6 & $9.8 \%$ & Tinggi \\
2. & $25-53$ & 44 & $72,1 \%$ & Sedang \\
3. & $7-24$ & 11 & $18 \%$ & Rendah \\
\hline Jumlah & & 61 & $100 \%$ & \\
\hline
\end{tabular}

Setelah mendapatkan kategori tersebut, peneliti mengambil subjek dengan kategori stres sedang dan tinggi. Kelompok kontrol dan eksperimen dipilih dengan cara random. Subjek terpilih dihubungi satu-persatu yang akhirnya mendapatkan 8 kelompok kontrol dan 7 kelompok kontrol.

\section{Desain Penelitian}

Penelitian ini menggunakan desain two group pre-test post-test design, yaitu desain eksperimen yang menggunakan kelompok eksperimen dan satu kelompok kontrol serta melakukan pengukuran sebelum dan sesudah pemberian perlakuan pada subjek (Latipun, 2006). Rancangan penelitian tersebut dapat dijelaskan sebagai berikut: 
Tabel 2. Desain penelitian two group pre-test post-test design

\begin{tabular}{llcl}
\hline Kelompok & Prates & Perlakuan & Pascates \\
\hline Eksperimen & $\mathrm{O} 1^{\prime \prime}$ & $\mathrm{X}$ & $\mathrm{O} 2^{\prime \prime}$ \\
Kontrol & $\mathrm{O} 1$ & - & $\mathrm{O} 2$ \\
\hline
\end{tabular}

Keterangan:

$\mathrm{O}_{1}{ }^{\prime \prime} \quad$ : Kelompok eksperimen sebelum diberikan perlakuan

$\mathrm{O}_{2}{ }^{\prime \prime} \quad$ : Kelompok eksperimen setelah diberikan perlakuan

$\mathrm{O}_{1} \quad$ : Kelompok kontrol sebelum diberikan perlakuan

$\mathrm{O}_{2} \quad$ : Kelompok kontrol setelah diberikan perlakuan

X : Perlakuan

\section{Metode Pengambilan Data}

Pengambilan data dilakukan dengan menggunakan skala stres. Stres terbagi dalam beberapa aspek, yaitu biologi, psikologi, dan sosial. Masingmasing aspek di atas diterjemahkan dalam beberapa indikator sebagaimana dapat diketahui dari Tabel 3 di bawah ini.

Tabel 3. Skala stres setelah diseleksi

\begin{tabular}{|c|c|c|}
\hline No & Aspek-aspek & Indikator \\
\hline 1 & Aspek biologi & $\begin{array}{l}\text { a. Munculnya respon fisiologis, misalnya individu lesu } \\
\text { dan kurang bergairah. } \\
\text { b. Merasa kelelahan ketika mengerjakan skripsi. }\end{array}$ \\
\hline 2 & $\begin{array}{l}\text { Aspek } \\
\text { psikologi }\end{array}$ & $\begin{array}{l}\text { a. Memiliki konsep berfikir (kognisi) dan penilaian } \\
\text { terhadap situasi-situasi yang memengaruhi. } \\
\text { b. Individu merasa terancam dan memiliki emosi negatif. }\end{array}$ \\
\hline 3 & Aspek sosial & $\begin{array}{l}\text { a. Interaksi sosial dengan teman memiliki respon stres } \\
\text { b. Interaksi dengan sosial dosen memiliki respon stres } \\
\text { c. Interaksi sosial dengan keluarga memiliki respon stres }\end{array}$ \\
\hline
\end{tabular}

Berdasarkan indikator-indikator di atas, peneliti menyusun sejumlah aitem skala stres. Skala stres yang telah disusun, diuji oleh pembimbing sebagai professional judgement serta diuji secara bahasa oleh lima mahasiswa nonpsikologi serta satu mahasiswa psikologi yang telah mengambil mata kuliah Penyusunan Skala Psikologi. Pelaksanaan uji coba (try out) skala stres dilakukan pada tanggal 17 juni 2012 sampai 21 juni 2012 kepada mahasiswa UIN Sunan Kalijaga yang memiliki karakteristik sama dengan subjek yang 
digunakan dalam penelitian ini. Kuesioner disebar kepada 40 mahasiswa. Skala ini menggunakan skala model likert dengan lima kateori jawaban, yaitu Selalu (SL), Sering (SR), Kadang-kadang $(K D)$, Jarang (JR), dan Tidak Pernah (TP).

Berdasarkan hasil try out didapatkan aitem yang sahih dan gugur. Aitem yang sahih ditentukan dengan koefisien $\left(r_{i t}\right)$ di atas 0,3. Pada skala stres awalnya aitem berjumlah 36 aitem, terdapat 9 aitem yang gugur sehingga jumlah aitem yang sahih adalah 27 item.

Uji reliabilitas dilakukan dengan teknik koefisien Alpha, sehingga diperoleh koefisien reliabilitas $(r)=$ 0,925. Dengan demikian, dapat disimpulkan bahwa skala tersebut cukup handal untuk mengukur tingkat stres mahasiswa yang sedang mengerjakan skripsi, dikarenakan skala tersebut memiliki koefisien reliabilitas mendekati 1,00 .

\section{Prosedur Penelitian}

Prosedur penelitian eksperimen ini terbagi dalam (1) persiapan penelitian, yang meliputi preliminary research dengan mengadakan wawancara kepada salah satu subjek. (2) menyusun alat ukur, (3) menyusun modul, (4) pelaksanaan eksperimen.

Persiapan penelitian meliputi persiapan perizinan, wawancara, obsevasi, studi awal untuk mendapatkan informasi mengenai subjek penelitian, dan sosialisasi mengenai eksperimen yang akan dilakukan kepada Pimpinan Program Studi Psikologi Fakultas Ilmu Sosial dan Humaniora UIN Sunan Kalijaga, untuk melakukan eksperimen yang melibatkan mahasiswa Fakultas Sains dan Teknologi yang dipilih berdasarkan indikator stres sebagai subjek dan fasilitator sebagai trainer. Pemilihan subjek dilakukan dengan cara memberikan alat ukur berupa skala stres yang telah diuji validitas dan reliabilitasnya.

Alat ukur disusun oleh peneliti berdasarkan aspek-aspek yang ada dalam dasar teori. Tahap berikutnya yaitu menyusun modul Pelatihan Pemaknaan Surat Al-Insyirah ditetapkan sebagai panduan dalam memberikan perlakuan kepada subjek.

Try out modul dan manipulation check dilakukan dalam waktu yang sama, yaitu tanggal 28 juli 2012 di rumah peneliti. Manipulation checks dilakukan oleh empat orang, yaitu tiga orang sebagai professional judgement dan peneliti. Pada sesi ini peneliti membagikan modul dan lembar check lalu peneliti menjelaskan isi dari modul dengan power point. Setelah itu, trainer mempraktikkan modul sesuai dengan jalannya pelatihan yang akan dilakukan sembari mengoreksi checklist dan mengoreksi modul. Hasil manipulation checks menunjukkan bahwa pada setiap aspek materi pelatihan telah terpenuhi.

Langkah selanjutnya adalah 
pemilihan subjek. Pemilihan subjek dilakukan dengan cara yang telah dijelaskan pada sesi sebelumnya.

Sebelum pelaksanaan penelitian, peneliti menyusun jadwal pelatihan dari awal hingga akhir. Adapun jadwal pelatihan Pemaknaan Surat Al-Insyirah adalah sebagai berikut:

Tabel 4. Jadwal Pelatihan Pemaknaan Al-Insyirah

\begin{tabular}{|c|c|c|c|c|}
\hline No & $\begin{array}{c}\text { Nama } \\
\text { Kegiatan }\end{array}$ & $\begin{array}{c}\text { Pukul } \\
\text { (Alokasi Waktu ) }\end{array}$ & Keterangan & $\begin{array}{c}\text { Penanggung } \\
\text { Jawab }\end{array}$ \\
\hline 1 & Pembukaan & 09.00 s.d 9.30 & $\begin{array}{l}\text { Pembukaan, } \\
\text { perkenalan. }\end{array}$ & Fasilitator \\
\hline 2 & $\begin{array}{l}\text { Lapang dada } \\
\text { dan } \\
\text { Pelepasan. }\end{array}$ & 9.30 s.d 11.30 & $\begin{array}{l}\text { Peserta latih agar } \\
\text { dapat berlapang } \\
\text { dada. }\end{array}$ & $\begin{array}{l}\text { Pemateri dan } \\
\text { fasilitator }\end{array}$ \\
\hline 3 & $\begin{array}{l}\text { Dibalik } \\
\text { kesulitan pasti } \\
\text { ada } \\
\text { kemudahan. }\end{array}$ & $11.30-13.00$ & $\begin{array}{l}\text { Peserta dilatih } \\
\text { untuk selalu memilih } \\
\text { positive felling }\end{array}$ & $\begin{array}{l}\text { Pemateri dan } \\
\text { fasilitator }\end{array}$ \\
\hline 4 & ISO & Menyesuaikan & Istirahat dan sholat & Fasilitator \\
\hline 5 & Etos Kerja & $13.00-15.25$ & $\begin{array}{l}\text { Peserta diberikan } \\
\text { video agar } \\
\text { bersemangat dan } \\
\text { kuat }\end{array}$ & $\begin{array}{l}\text { Pemateri dan } \\
\text { fasilitator }\end{array}$ \\
\hline 6 & Penutup & $15.25-16.00$ & Acara penutup & Moderator \\
\hline
\end{tabular}

Pelaksanaan eksperimen dilaksanakan pada tanggal 8 Agustus 2012 bertempat di ruang audio visual Fakultas Ilmu Sosial dan Humaniora UIN Sunan Kalijaga Yogyakarta dengan persiapan pelatihan dimulai pukul 7.30 sampai 08.00 WIB. Ruang audio visual dipilih karena ruangan tersebut cukup nyaman dilengkapi dengan $\mathrm{LCD}, \mathrm{AC}$, dan sound yang mendukung jalannya pelatihan.
Beberapa hal yang membuat pelatihan mundur hingga tiga puluh menit, antara lain karena ada peserta yang tiba-tiba izin untuk bimbingan terlebih dahulu. Peserta yang awalnya bersedia hadir ternyata tidak hadir dan tidak memberikan konfirmasi kepada peneliti sehingga peneliti harus menunggu dan menghubungi subjek. Adapun proses eksperimen sebagai berikut: 
Tabel 5. Pelaksanaan Eksperimen

\begin{tabular}{|c|c|c|c|c|}
\hline No & $\begin{array}{c}\text { Nama } \\
\text { Kegiatan }\end{array}$ & $\begin{array}{c}\text { Pukul } \\
\text { (Alokasi Waktu) }\end{array}$ & Keterangan & $\begin{array}{c}\text { Penanggug } \\
\text { Jawab }\end{array}$ \\
\hline 1 & Pembukaan & 09.30 s.d 09.50 & $\begin{array}{l}\text { Pembukaan, } \\
\text { perkenalan. }\end{array}$ & Fasilitator \\
\hline 2 & $\begin{array}{l}\text { Lapang dada } \\
\text { dan } \\
\text { Pelepasan. }\end{array}$ & 09.50 s.d 11.30 & $\begin{array}{l}\text { Peserta dilatih agar } \\
\text { dapat berlapang } \\
\text { dada. }\end{array}$ & $\begin{array}{l}\text { Pemateri dan } \\
\text { fasilitator }\end{array}$ \\
\hline 3 & $\begin{array}{l}\text { Di balik } \\
\text { kesulitan } \\
\text { pasti ada } \\
\text { kemudahan }\end{array}$ & $11.30-12.00$ & $\begin{array}{l}\text { Peserta dilatih untuk } \\
\text { selalu berpositif } \\
\text { felling }\end{array}$ & $\begin{array}{l}\text { Pemateri dan } \\
\text { fasilitator }\end{array}$ \\
\hline 4 & ISO & Menyesuaikan & istirahat dan sholat & Fasilitator \\
\hline 5 & Etos Kerja & $13.30-15.25$ & $\begin{array}{l}\text { Peserta diberikan } \\
\text { video agar } \\
\text { bersemangat dan } \\
\text { kuat }\end{array}$ & $\begin{array}{l}\text { Pemateri dan } \\
\text { fasilitator }\end{array}$ \\
\hline 6 & Penutup & $15.25-16.00$ & Acara penutup & Moderator \\
\hline
\end{tabular}

Secara umum dalam pelatihan ini tidak banyak yang berubah, hanya pada sesi perkenalan permainan zip-zap diganti dengan perkenalan satu per satu dengan gaya yang unik dan berbeda untuk menyingkat waktu. Sebelum pelatihan dimulai terlebih dahulu peneliti melakukan building rapport kepada semua subjek dan memastikan subjek dapat mengikuti pelatihan dari awal hingga akhir.

Fasilitator memulai acara pelatihan dan kemudian memperkenalkan data diri trainer. Para peserta menyimak dengan antusias, kemudian dipandu fasilitator untuk memperkenalkan diri. Jumlah peserta yang hadir pada sesi ini adalah 8 orang. Selanjutnya fasilitator mempersilakan trainer untuk memberikan materi pelatihan. Trainer mengucapkan salam, melakukan building rapport, dan berkenalan dengan peserta. Peserta mengenakan name-tag. Trainer melakukan dialog dengan peserta, "Apa tiga kata yang dijadikan satu kalimat menjadikan racun buat kita?" Pertanyaan ini sebagai perantara untuk menuju kepada materi.

Trainer mulai membahas slide pertama yang berisi tentang aspek kelapangdadaan. Pada sesi pertama ini, trainer menjelaskan tentang asbabun nuzul turunnya Surat Al- Insyirah. Diharapkan peserta dapat mengetahui 
bahwa setiap hamba pasti mempunyai ujiannya sendiri, tidak mengenal itu nabi atau orang, selanjutnya trainer memberikan materi tentang masalah. Pada sesi ini peserta diberikan pertanyaan tentang apa masalah dan menurut mereka masalah itu menguatkan atau melemahkan. Melalui dialog ini, diharapkan peserta dapat mengingat kembali (recall) tentang arti sebuah masalah yang ada dalam diri peserta serta dapat mensinkronkan antara realita dan sesungguhnya makna sebuah masalah tersebut. Setelah itu peserta dilatih untuk merubah kata-kata negatif menjadi positif.

Pada slide selanjutnya trainer menjelaskan tentang kelapangdadaan. Pada sesi ini peserta akan diberikan materi tentang hidup adalah ujian. Isi dari materi tersebut antara lain manusia harus menyadari bahwa hidup adalah ujian, kumpulan dari masalah. Semakin tinggi kedudukan seseorang semakin tinggi atau semakin sulit ujiannya. Dengan demikian diharapkan peserta secara kognitif dapat mengerti bahwa segala macam ujian adalah wujud kasih sayang Allah dan sebagai upaya untuk meningkatkan derajat hamba-Nya. Selain itu peserta tahu bahwa hidup memang sebuah ujian dan sebagai hamba harus siap menjalaninya. Selanjutnya trainer menampilkan video. Video tersebut berisi tentang perjuangan para pemenang. Seorang pemenang adalah seseorang yang mampu bangkit dari jatuh. Setelah menonton peserta diminta memberikan tanggapan akan hikmah di balik video tersebut.

Materi selanjutnya adalah peserta diberikan pemaknaan Surat Al-Insyirah ayat satu sampai empat tentang sebuah kelapangdadaan sebelum peseta dilatih untuk teknik pelepasan masalah. Setelah mengetahui makna dari ayat tersebut peserta diberikan materi, bahwa sebuah masalah jika dijadikan beban, maka semakin lama akan terasa semakin berat, sehingga perlu adanya pelepasan masalah. Trainer selanjutnya memberikan contoh kepada peserta tentang salah satu teknik pelepasan masalah lalu peserta mempraktikan dengan cara berpasangan.

Sesi selanjutnaya adalah ranah di balik kesulitan ada kemudahan. Pada awal sesi, trainer memberikan slide tentang pemaknaan Surat Al-Insyirah lima hingga enam ayat agar peserta mengetahui acuan yang dipakai dalam pembahasan pada sesi ini. Peserta di berikan kata-kata hikmah. Pemateri memperlihatkan sebuh video kepada peserta tentang lilin harapan. Video tersebut berisi cerita tentang empat buah lilin di mana ketika lilin damai, iman, dan cinta memilih untuk padam karena merasa sudah tidak berharga. Ketika seorang anak takut akan kegelapan karena ketiga lilinnya sudah mati, lalu lilin harapan yang masih bersinar berkata, bahwa dia akan menghidupkan kembali tiga lilin yang sudah mati 
tersebut. Video dapat merangsang secara kognisi dan afeksi bahwa sebagai hamba Allah dilarang untuk berhenti berharap.

Trainer memberikan tebakan kepada peserta. Dalam tebak-tebakan tersebut ada seseorang yang sedang berjuang dan menemui sebuah masalah. Bagaimana jalan keluarnya, peserta memberikan jawaban yang bermacammacam. Melalui dialog ini peserta dapat mengambil hikmah bahwa satu masalah saja memiliki berbagai pemecahan, sehingga hal ini dapat diartikan bahwa satu kesulitan memiliki jalan lebih dari satu.

Selanjutnya, peserta diberikan gambaran tetang dua orang penggali di mana satu orang penggali tetap tegar dan berusaha walaupun tertinggal, dan satunya lagi menyerah, padahal beberapa galian lagi dia sudah akan mendapatkan emas. Melalui sesi ini peserta mampu mengambil makna dari cerita tersebut, bahwa manusia tidak tahu apa yang ada di depan mata, kapan ikhtiar akan sampai. Oleh karena itu manusia selayaknya tidak menyerah.

Trainer memberikan kunci-kunci untuk meraih kemudahan. Kunci-kunci meraih kemudahan dengan cara selalu mendekatkan diri kepada Allah melalui amalan-amalan. Materi ini memberikan pelajaran bahwa sebagai seorang hamba dalam berikhtiar selalu diminta untuk mendekatkan diri kepada Allah SWT.

Sesi ketiga diawali dengan pembahasan hadits. Pemateri memberikan sebuah hadits riwayat AlBaihaqi dari Ibnu Abbas. Disebutkan Rasulullah saw. bersabda, "Jagalah lima sebelum datang lima, yakni hidupmu sebelum matimu, sehatmu sebelum sakitmu, senggangmu sebelum sibukmu, mudamu sebelum tuamu, dan kayamu sebelum miskinmu." Pemateri menjelaskan tentang makna dari hadits tersebut. Bahasan selanjutnya adalah game optimis dan pesimis. Dalam game tersebut, peserta diminta mengangkat sesuatu. Pada sesi pertama, peserta dibuat menjadi seseorang yang pesimis, lalu optimis. Setelah itu peserta diajak untuk merasakan perbedan antara ketika pesimis dan optimis. Peserta dapat membedakan rasa berjuang dengan keoptimisan dan kepesimisan.

Selanjutnya dijelaskan oleh trainer bahwa jika manusia ingin sukses maka hal tersebut ditentukan oleh hari ini dan selanjutnya. Di sini, perubahan untuk selalu memperbaiki diri muncul, setelah materi peserta diberikan worksheet yang berisi dua kolom. Kolom sebelah kiri bertuliskan "kemarin aku adalah...". Pada kolom ini peserta diminta untuk mengisi hal-hal yang dianggap negative. Selanjutnya, kolom sebelah kanan berisikan, "Sekarang aku adalah...". Peserta diminta untuk mengisikan hal-hal yang positif, dalam hal ini lawan dari sesuatu yang negatif yang ada pada diri peserta. Setelah itu peserta diminta untuk membaca tulisannya dalam hati tersebut, lalu fasilitator meminta peserta untuk 
menghapus, menutup, atau menyobek bagian sebelah kiri dengan penghapus atau kertas. Melalui cara ini, peserta dapat mengubah sesuatu yang negatif dalam dirinya menjadi sesuatu yang positif, serta menghapus sisi negatif dirinya di masa lalu.

Trainer kemudian menjelaskan tentang impian, apa pentingnya impian, sambil menanyakan apa impian peserta dalam waktu dekat. Setelah itu, peserta diberikan prinsip SMART, yaitu prinsip yang digunakan dalam menuliskan citacita atau impian yang akan dicapai. Peserta diberi kertas lalu diminta menuliskan sesuai apa yang diminta oleh trainer. Awalnya pemateri meminta peserta untuk menuliskan keinginan atau goal yang akan dicapai dalam waktu dekat (misalnya wisuda pada pada bulan Agustus atau Desember), lalu apa usaha untuk mencapainya (misalnya apa yang akan dilakukan minggu depan, dua minggu kemudian), dan siapa yang akan membantumu meraihnya (misalnya orang tua, dosen pembimbing, dan lainlain). Setelah itu trainer melakukan relaksasi yang berisi perjalanan menuju impian yang sudah dikemas dengan Surat Al-Insyirah.

Sesi penutupan diisi dengan pemberian testimoni. Testimoni dilakukan dengan cara wawancara satu per satu dengan peserta. Setelah itu, peserta merangkum acara, pengisian pascates, pembagian doorprize, dan ucapan terimakasih dari penyelenggara.
Acara selesai kurang lebih pukul 4 sore.

Pengambilan data pascates dilakukan langsung setelah pelatihan, yakni pada hari Rabu, tanggal 8 Agustus 2012 bertempat di ruang audio visual dan depan ruang audio visual untuk kelompok kontrol. Pengambilan data pascates untuk kelompok kontrol terkendala beberapa hal, antara lain ada subjek yang tidak dapat hadir dikarenakan ibunya di rumah sakit sedang dalam perawatan sakit jantung. Selain itu ada yang sudah bersedia hadir namun tanpa konfirmasi ternyata mengundurkan diri. Hal tersebut yang mengakibatkan jumlah kelompok kontrol dan eksperimen berbeda. Subjek yang ibunya sakit mengisi pascates sehari setelah hari $\mathrm{H}$ pelatihan dengan cara peneliti mendatangi subjek ke rumah sakit.

\section{HASIL PENELITIAN}

\section{Deskripsi Data}

Hasil analisis statistik didasarkan atas skor tingkat stres pada mahasiswa yang sedang mengerjakan skripsi. Hasil skor stres pada mahasiswa yang sedang mengerjakan skripsi terhadap 61 mahasiswa Fakultas Sains dan Teknologi non-kependidikan yang sedang mengerjakan skripsi terdiri atas tiga kategori, yaitu rendah, sedang, dan tinggi. Semakin skor tinggi diasumsikan semakin tinggi tingkat stres pada mahasiswa tersebut. Adapun hasil 
kategorisasi tingkat stres mahasiswa didikan yang sedang mengerjakan skipsi Fakultas Sains dan Teknologi non-kepen- sebagai berikut.

Tabel 6. Kategorisasi tingkat stres pada Mahasiswa Sains dan Teknologi non-kependidikan.

\begin{tabular}{crrrl}
\hline \multirow{2}{*}{ No } & \multirow{2}{*}{ Skor } & \multicolumn{2}{c}{ Frekuensi } & \multirow{2}{*}{ Kategorisasi } \\
\cline { 2 - 4 } & & $\mathrm{F}$ & $\mathrm{F} \%$ & \\
\hline 1. & $54-66$ & 6 & $9.8 \%$ & Tinggi \\
2. & $25-53$ & 44 & $72,1 \%$ & Sedang \\
3. & $7-24$ & 11 & $18 \%$ & Rendah \\
Jumlah & & 61 & $100 \%$ & \\
\hline
\end{tabular}

Tabel 7. Deskripsi Statistik Prates dan Pascates Kelompok Eksperimen

\begin{tabular}{lllll}
\hline Kategori & SD & Mean & Minimum & Maksimum \\
\hline Pre Test & 10,875 & 43,62 & 29 & 66 \\
Post Test & 20,105 & 25,75 & 0 & 53 \\
\hline
\end{tabular}

Berdasarkan data di atas dapat dideskripsikan bahwa ada perbedaan prates dan pascates pada kelompok eksperimen. Hal ini di dasarkan hasil dari analisis statistik Wilcoxon Signed Rank Test mendapatkan $\mathrm{Z}=-2,243$ dengan nilai $p=0,025 \quad(p<0,05$, signifikan).
Dengan demikian, dapat disimpulkan bahwa ada perbedaan yang signifikan pada kelompok eksperimen sebelum dan sesudah diberikan perlakuan.

Deskripsi statistik skor prates dan pascates kelompok kontrol dapat disajikan sebagai berikut:

Tabel 8. Deskripsi Statistik Hasil Pascates dan Prates Kelompok Kontrol

\begin{tabular}{lcccc}
\hline Kategori & SD & Mean & Maksimum & Minimum \\
\hline Post Test & 8,73144 & 45,2857 & 29.00 & 55,00 \\
Pre Test & 7,61577 & 46,0000 & 33.00 & 54,00 \\
\hline
\end{tabular}

Berdasarkan data di atas, maka dapat dideskripsikan bahwa tidak ada perbedaan prates dan pascates pada kelompok kontrol. Hal ini didasarkan hasil uji statistik yang menghasilkan nilai $p=0,611 \quad(p>0,05$, tidak signifikan). Deskripsi statistik kelompok kontrol dan kelompok ekperimen dapat disajikan sebagai berikut: 
Efektivitas Pelatihan Pemaknaan Surat Al-insyirah Untuk Mengurangi Stres Mahasiswa ....

Tabel 9. Deskripsi Statistik Pascates Kelompok Kontrol dan Eksperimen

\begin{tabular}{ccccc}
\hline Kategori & SD & Mean & Minimum & Maksimum \\
\hline Post Test & 18,33887 & 35,2000 & 0 & 54 \\
Kelompok & 0,5333 & 0,51640 & 1,00 & 2 \\
\hline
\end{tabular}

Data di atas menyatakan bahwa secara empirik Pelatihan Pemaknaan Surat Al-Insyirah dapat mengurangi tingkat stres mahasiswa yang sedang mengerjakan skripsi. Hal ini didasarkan uji statistik dengan menggunakan Man Whitney U. Suseno (2011) memaparkan Mann Whitney $U$ adalah teknik analisis statistik non-parametrik yang digunakan untuk menguji ada tidaknya perbedaan pada satu variabel tergantung, bersifat interval atau rasio, dan disebabkan oleh satu variabel bebas yang bersifat nominal. Berdasarkan hasil analisis dengan menggunakan Mann Whitney $U$ diketahui bahwa skor pascates antara kelompok kontrol dan eksperimen $\mathrm{Z}=$ 1,971 dengan nilai $p=0,049(p<0,05$, signifikan) sehingga dapat disimpulkan bahwa ada perbedaan skor pascates antara kelompok eksperimen dan kelompok kontrol.

\section{PEMBAHASAN}

Subjek pada pelatihan ini adalah mahasiswa Fakultas Sains dan Teknologi UIN Sunan Kalijaga non-kependidikan yang memiliki skor $<=26$. Hal ini berarti subjek yang dipilih adalah yang memiliki kategori tingkat stres tinggi dan sedang. Berdasarkan hasil analisis Mann
Whitney $U$ dapat ditunjukkan bahwa pascates perbandingan antara kelompk kontrol dan eksperimen menghasilkan nilai $Z=-1.971$ dengan nilai $p=0,049$ $(p<0,05)$, sehingga dapat disimpulkan bahwa ada perbedaan yang signifikan antara skor stres antara kelompok eksperimen dan kelompok kontrol. Sedangkan hasil analisis Wilcoxon Signed Rank pascates dan prates kelompok eksperimen mendapatkan nilai $Z=-2.243$ dengan nilai $p=0,025$ $(\mathrm{P}<0,05)$, sehingga dapat disimpulkan bahwa ada perbedaan tingkat pada kelompok eksperimen sebelum dan setelah diberi perlakuan. Skor stres pada subjek setelah diberi perlakuan cenderung turun.

Hasil penelitian menunjukkan bahwa pelatihan pemaknaan Surat AlInsyirah cukup efektif dalam mengurangi stres mahasiswa yang sedang mengerjakan skripsi. Hal ini dikarenakan Surat Al-Insyirah mengandung aspek kelapangdadaan. Nashori (2008) mendeskripsikan kelapangdadaan adalah suatu kondisi psikospiritual yang ditandai oleh kemampuan menerima berbagai kenyataan yang tidak menyenangkan dengan tenang dan terkendali. Orang yang lapang dada 
memiliki kekuatan dalam jiwanya untuk bertahan dan tidak berputus asa ketika menghadapi berbagai situasi yang secara objektf tidak menyenangkan secara psikis dan menyakitkan secara fisik. Semakin tinggi kelapangdadaan seseorang semakin mampu ia menghadapi realitas yang beragam, termasuk tidak menyenangkan.

Ketika seseorang mampu untuk bertahan dan menerima realitas yang ada, baik yang diinginkan maupun tidak diinginkan, maka secara psikologis individu tersebut termasuk dalam ciri orang yang sehat. Sebagaimana diungkapkan oleh Allport (Schultz,1991) bahwa seseorang yang sehat tidak memaksakan bahwa sesuatu harus sesuai dengan keinginan-keinginannya. Seseorang yang sehat adalah seseorang yang menerima realitas apa adanya (Schultz, 1991).

Dalam pelatihan ini peserta dilatih untuk berlapang dada antara lain mengerti bahwa hidup ini adalah ujian dari Allah dan berfungsi untuk menaikan derajat hamba-Nya dan memperkuat ketahanan hamba-Nya, menyadari masalah yang dihadapinya, menerima kenyataan dan ikhlas melepaskan masalah. Hal ini relevan dengan pemaknaan Surat Al-Insyirah di mana larut dalam kesedihan itu bukanlah solusi. Selain itu, peserta juga dilatih untuk memberikan afirmasi atau kalimat positif agar menjadi dirinya lebih positif. Pada ranah ini terdapat juga cara menangani stres sebagaimana yang dipaparkan Yekti (2010) bahwa salah satu cara menangani stress, yaitu dengan mendekatkan diri kepada Tuhan.

Berdasarkan pemaparan di atas maka dapat disimpulkan bahwa aspek kelapangdadan pada pemaknaan Surat Al-Insyirah mampu untuk mengurangi stres pada mahasiswa yang sedang mengerjakan skripsi. Ketika seseorang mampu untuk mengendalikan dan menangani stresnya dengan cara mengetahui masalah, tahu apa hikmah di balik masalah, dan mampu untuk mengikhlaskan masalah tersebut, maka seseorang tersebut mampu menerima masalah atau realita yang di hadapi, tahu hikmah yang ada di dalamnya, dan mampu untuk melakukan koping atas masalah tersebut sehingga dapat mengurangi tekanan yang ada di dalam jiwa.

Selanjutnya Surat Al-Insyirah juga mengandung makna di balik kesulitan pasti ada kemudahan. Pada makna ini ada larangan untuk berputus asa, selalu berharap, ridha, sabar, serta selalu berfikir positif. Percaya bahwa Allah SWT memberikan jalan kemudahan bagi setiap hamba-Nya yang sedang dihampiri kesulitan. Salah satu ciri atau tipe orang yang sehat jiwa menurut Starbuck adalah optimis dan gembira (Rakhmat, 2008). Orang yang sehat mengungkapkan bahwa pahala sebagai hasil jerih payah yang diberikan Tuhan (Rakhmat, 2008). Pada pelatihan ini peserta dilatih untuk 
membuat bingkai ulang apa yang dikeluhkan, mengambil hikmah dari sebuah kejadian. Pada sesi ini terdapat hal yang juga menjadi cara dalam menangani stres, yaitu mengambil makna dan beranggapan positif sebagaimana yang dipaparkan oleh Kuhsari (2012). Anggapan positif tersebut juga berhubungan dengan faktor yang memengaruhi stres, yaitu faktor psikologis terutama persepsi (Santrock, 2003). Melalui aspek dan faktor di atas, peserta dilatih untuk tangguh dalam berharap. Selalu berfikir dan berperasaan positif terhadap apa yang sedang dijalani termasuk masalah yang sedang dihadapi. Selalu bergembira dan positif adalah ciriciri dari seseorang yang sehat secara mental, dan ketika seseorang mampu untuk selalu berfikir positif dan tidak mudah putus asa, serta bergembira maka hidupnya semakin sehat. Dengan demikian, dapat disimpulkan bahwa aspek ini mampu mengubah kognitif peserta agar lebih positif sehingga dapat mengurangi stres mahasiswa yang sedang mengerjakan skripsi.

Aspek selanjutnya adalah etos kerja. Dengan etos kerja ini diharapkan peserta mampu untuk menyadari bahwa hidup adalah pergolakan manusia dengan waktu. Sebagai muslim dilarang untuk menyia-nyiakan waktu, serta hidup seseorang harus memiliki tujuan atau planning, terus berproses dan memperbaiki diri. Dalam pelatihan ini peserta dilatih untuk membuat perubahan dalam dirinya, terus berproses dan tidak menyia-nyiakan waktu, serta membuat planing dalam hidupnya. Pada sesi ini, peserta diberikan materi yang berisi tentang "jangan sia-siakan waktu". Dengan demikian sebagai manusia, sebaiknya terus berproses karena menurut Prokop (Faridah, 2011), salah satu faktor yang memengaruhi stres adalah faktor durasi. Semakin seseorang larut dalam stresor maka semakin memengaruhi tingkat stres. Melalui sesi ini peserta dapat berlatih untuk tetap optimis, mempunyai planning masa depan dan tidak menyia-nyiakan waktu sehingga seorang individu lebih fokus kepada tujuan yang diperoleh bukan lagi hambatan yang mereka jalani.

Adapun faktor di luar materi yang turut mendukung dalam proses pelatihan ini adalah keadaan ruangan yang menurut subjek nyaman. Jumlah subjek yang tidak banyak sehingga memungkinkan suasana lebih kooperatif. Keadaan subjek yang cenderung homogen dan memiliki masalah yang relatif sama sehingga menyebabkan subjek lebih terbuka, serta trainer yang mampu membawakan materi dengan santai namun serius sehingga subjek pelatihan lebih mampu untuk banyak share terhadap masalahnya dan berkomunikasi dengan trainer.

Kelemahan dari pelatihan ini adalah jumlah subjek yang tidak memenuhi target di mana target awal peneliti adalah 15, namun yang datang 
hanya 8 subjek. Sebanyak 7 subjek yang tidak hadir dikarenakan tiba-tiba ada acara, ada janji dengan dosen, dan ada juga yang tanpa keterangan. Selain itu dimungkinkan karena kelemahan peneliti dalam menarik subjek untuk mengikuti pelaihan sehingga peserta tidak sesuai dengan target.

\section{SIMPULAN DAN SARAN}

\section{Simpulan}

Hasil uji statistika dengan menggunakan teknik analisis Mann Whitney $U$ dapat diungkap bahwa ada perbedaan skor pascates antara kelompok eksperimen dan kelompok kontrol. Hasil uji statistik dengan Wilcoxon Signed Ranks untuk membandingkan pascates dan prates antara kelompok eksperimen dan kontrol mengungkap bahwa ada perbedaan skor prates dan pascates pada kelompok eksperimen, sehingga dapat disimpulkan bahwa pelatihan pemaknaan Surat AlInsyirah cukup efektif dalam mengurangi stres mahasiswa yang sedang mengerjakan skripsi. Kelompok yang diberikan perlakuan lebih rendah tingkat stresnya daripada yang tidak di berikan perlakuan. Pada kelompok eksperimen tingkat stres subjek setelah diberikan perlakuan lebih rendah daripada sebelum diberikan perlakuan.

\section{Saran}

Berdasarkan simpulan yang telah dipaparkan, peneliti memberikan sejumlah saran. Pertama, saran kepada peserta. Para peserta supaya dapat mengembangkan lebih lanjut materi yang sudah diajarkan dalam pelatihan dan menerapkannya dalam kehidupan sehari-hari karena pelatihan ini dinilai cukup efektif dalam menguragi stres mahasiswa yang sedang mengerjakan skripsi.

Kedua, saran kepada para trainer. Berdasarkan hasil yang dikemukakan diatas diketahui bahwa pelatihan pemaknan Surat al-Insyirah dapat dipergunakan untuk menurunkan tingkat stres mahasiswa yang sedang mengerjakan skripsi. Oleh karena itu, perlu diperhitungkan dan dikembangkannya pelatihan ini agar lebih baik dalam hal pengemasannya.

Ketiga, saran kepada para peneliti. Perlu diadakannya penelitian lebih lanjut tentang pelatihan Pemaknaan Surat AlInsyirah ini mungkin dapat dikemas dengan lebih menarik agar peserta lebih antuias dan mampu memberikan efek positif yang lebih baik lagi. Pelatihan ini juga dapat dikembangkan dengan cara menggunakannya untuk intervensi yang lain, misalnya meningkatkan kesabaran, etos kerja, dan lain-lain. Peneliti juga menyarankan agar dalam penelitian selanjutnya menggunakan subjek yang lebih banyak sesuai dengan kaidahkaidah yang ada agar hasil pelatihan dapat digeneralisasikan.

Keempat, saran kepada institusi. 
Pelatihan ini dapat dijadikan alternatif untuk mengurangi stres mahasiswa yang sedang mengerjakan skripsi. Hal ini dikarenakan penelitian ini terbukti cukup efektif dalam mengurangi stres mahasiswa yang sedang mengerjakan skripsi.

\section{DAFTAR PUSTAKA}

Ano, G.G. \& Vasconcelles, E.B. (2005). Religious Coping and Psychological Adjustment to Stress: A Meta-Analysis. Journal of Clinical Psychology, 61(4), 461-480.

Chaplin, J. P. (2006). Kamus Lengkap Psikologi. Jakarta: PT Raja Grafindo Persada.

Compton,W.C. (2005). An Introduction to Positive Psychology. United States of America : Thompson Learning, Inc.

Dahlan, Z. (1999). Qur'an Karim dan Terjemah Artinya. Yogyakarta: UII Press.

Farida, Y. (2011). Dahyatnya Surat Alam Nasyrah. Yogyakarta: Mutiara Media.

Hadi, S. (2003). Metodologi Reserch. Yogyakarta: Andi Offset.
Heerjan, S. (1987). Apa itu kesehatan jiwa? Suatu pengantar ke bidang kesehatan jiwa dan kesehatan jiwa masyarakat. Jakarta: Fakultas Kedokteran Universitas Indonesia

Kuhsari, I.H. (2012). Al-Qur'an dan Tekanan Jiwa. Jakarta: The Islamic College.

Latipun. (2006). Psikologi Eksperimen. Malang: UMM Press.

Mappiare, A. (1983). Psikologi Orang Dewasa. Surabaya: Usaha Nasional.

Nashori, F. (2008). Psikologi Sosial Islami. Bandung: PT Refika Aditama.

Rakhmat, J. (2008). Psikologi Agama. Jakarta: PT Raja Grafindo Persada.

Rohmah, F. A. (2006). Pengaruh Diskusi Kelompok dan Pelatihan Efikasi Diri untuk Menurunkan Stres Mahasiswa yang Sedang Mengerjakan Skripsi. Humanitas, Indonesian Psychological Journal, 3 (1).

Santrock, J.W. (2003). Adolescence Perkembangan Remaja.Edisi Empat. Jakarta: Erlangga. 
Santrock, J.W. (2007). Adolescence. Suseno, M.N. (2011). Suplemen Modul New York: Mc Graw-Hill. Praktikum Statistika. Yogyakarta: International Edition.

Schultz, D.(1991). Psikologi Pertumbuhan.Terjemahan. Yekti, M.A.W. (2010). Cara Jitu Yogyakarta: Kanisius.

Shenoy, U.A. (2000). Colledge-stress Symtom-expretion in International Student A Comperative Study. (Tanggal akses 28 Februari 2012, Pukul 10:14 WIB) Laboratorium Psikologi UIN Sunan Kalijaga. Mengatasi Stres. Yogyakarta: Penerbit Andi.

Yulianti, A. (2010). Pengaruh Brain Gym terhadap Penurunan Tingkan Stres pada Mahasiswa Program Studi DIV Tingkat Akhir. Skripsi Online. Surakarta: Universitas Muhamadiyah Surakarta. 